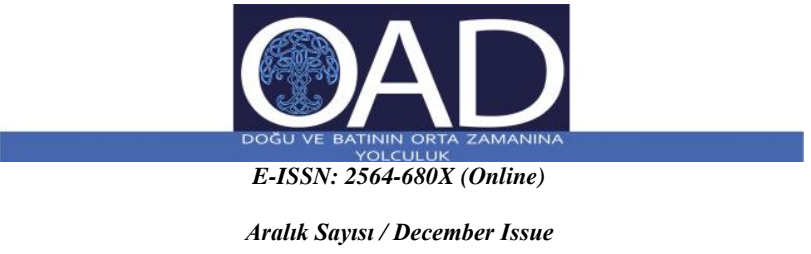

Yıl 3, Sayı 2 / Year 3, Issue 2

ATIF BILGISI / REFERENCE INFORMATION

MISIRLI, Arif; ÖZGÜVEN, H. Burcu, “Bizans Dönemi’nde Kentin Dönüşümü: Hamam ve Hamam-Gymnasium Yapılarının Yeniden Kullanımı”, Ortaçă̆ Araştırmaları Dergisi, III/II, Aralık 2020, s. 391-401

Makale Türü: Sanat Tarihi Araştırma

DOI No: https://doi.org/10.48120/oad.816834

Gelis Tarihi / Received: 27 Ekim 2020 Online Yayın: 26 Aralık 2020
Kabul Tarihi / Accepted: 25 Kasim 2020

Published Online: 26 December 2020

\title{
Bizans Dönemi’nde Kentin Dönüşümü: Hamam ve Hamam-Gymnasium Yapılarının Yeniden Kullanımı*
}

\author{
Arif MISIRLI ${ }^{*+}$ \\ H. Burcu ÖZGÜVEN²+ \\ ${ }^{I}$ Dr. Öğr. Üyesi, Trakya Üniversitesi Mimarlık Fakültesi Mimarlık Bölümü, EDIRNE. \\ *arifmisirli@trakya.edu.tr \\ +ORCID: 0000-0003-2183-0532 \\ ${ }^{2}$ Prof. Dr., Trakya Üniversitesi Mimarlık Fakültesi Mimarlık Bölümü, EDIRNE. \\ *bozguven@hotmail.com \\ +ORCID: 0000-0001-9541-5302
}

$\ddot{\boldsymbol{O}}_{\boldsymbol{z}}$ - Antik Çă̆ kentlerinde yerleşim karakterinin tanımlanmasında kamu yapıları önemli yere sahiptir. Kentlerin önem ve kapasitesi hamam, hamam-gymnasium, tiyatro ya da agora gibi kamusal yapılar ile birlikte değerlendirilmektedir. Ancak 4. ve 7. yüzyıllar arasında toplumsal yaşamda ve ekonomide görülen değişimler, kamusal yapıların işlevlerinin devamlılığının sonlanmasına neden olmuş, bu durum da yapıların dönüşümlerine ve yeniden kullanımlarına ilişkin sonuçlar doğurmuştur.

$\mathrm{Bu}$ çalışmanın konusunu oluşturan hamamlar ve hamam-gymnasium kompleksleri, kentlerde halkın yıkanma gereksinimini karşılayan, ayrıca eğitim, spor etkinlikleri ve kültürel gereksinimlerine de cevap veren kentsel birimlerdir. Arkeolojik kanıtlara dayanarak hamamların ve hamamgymnasium komplekslerinin kentsel işlevlerinin 5.-6. yüzyıllarda değişmeye başladığı gözlenir. Özellikle Hıristiyanlığın yayılmaya başlaması ile birlikte kilisenin ruhsal temizliğe önem verilmesi gerektiğini vurgulaması söz konusu işlevlerin zamanla azalmasına neden olmuştur.

$\mathrm{Bu}$ çalışmada hamamların ve hamam-gymnasium komplekslerinin Geç Antik Dönem'de başlayan dönüşümünün yanı sıra Bizans Dönemi'ndeki konumu ve kullanımı incelenmiş; Geç Antik ve Bizans kenti morfolojisinin hamam ve hamam-gymnasium komplekslerinin dönüşümü üzerinden analiz edilmesi amaçlanmıştır. İnceleme kapsamında söz konusu yapılarda meydana gelen dönüşümün nasıl oluştuğu ve sonuçta yeni işlevin ne olduğu sorgulanmaktadır.

Bu doğrultuda Aizanoi, Amorium, Aphrodisias, Arykanda, Assos, Elaiussa Sebaste, Ephesos, Hierapolis, Miletos, Myra-Andriake, Olympos, Patara, Priene, Rhodiapolis, Sagalassos, Sardes, Side ve Tralleis kentlerinde yer alan hamamların ve hamam-gymnasium komplekslerinin dönüşümleri incelenmiştir. İşlevsel nedenlerle kentte geniş bir alanı kapsayan bu yapılarda özgün işlevini devam ettiren örnekler olduğu gibi, özgün işlevini kaybedip kullanımdan çıktıktan sonraki dönüşümleri, yapının bir bölümünün ya da yapılardan geriye kalan arsanın kullanılması şeklinde gerçekleştirilmiştir. Arkeolojik kazı raporları sonucu hamamların ve hamam-gymnasium komplekslerinin dinsel amaçlı dönüşümün yanı sıra, konut amaçlı, endüstriyel, savunma ve yönetsel amaçlı olarak farklı kullanımlarının olduğu saptanmıştır. Söz konusu yapıların dönüşümünde dinsel örgütlenmenin değişimi başta olmak üzere, kentsel alanın daralması sonucu arsa yetersizliğinin oluşması ve ekonomik hayatın yeni mecralarda gelişmesi gibi etkenlerin rol oynadığı dikkat çekmektedir.

Anahtar Kelimeler-Geç Antik Çağ ve Bizans kenti, hamam, hamam-gymnasium kompleksi, dönüşüm

\section{Transformation of the City in the Byzantine Period: Reuse of Bath and Bath-Gymnasium Buildings}

Abstract-Public buildings have an important place in defining the settlement character in ancient cities. The importance and capacity of cities are evaluated together with public buildings such as baths, bath-gymnasium complex, theater or agora. However, the changes in social life and economy between the fourth and seventh centuries caused the end of the functions of public buildings, which resulted in the transformation and reuse of the buildings.

\footnotetext{
* Makale yazımı yazar etki oranı: 1.yazar: $\% 50,2$.yazar: $\% 50$.
} 
The baths and bath-gymnasium complexes, which are the subject of this study, are urban units that meet the bathing needs of the people in the cities and also respond to educational, sports activities and cultural needs. Based on archaeological evidence, it is observed that the urban functions of baths and bath-gymnasium complexes began to change in the fifth-sixth centuries. Especially with the spread of Christianity, the church's emphasis on spiritual cleansing caused the aforementioned functions to decrease over time.

In this study, the transformation of baths and bath-gymnasium complexes that started in the Late Antique period, as well as their location and use in the Byzantine Period are examined. Besides, it is aimed to analyze the morphology of Late Antique and Byzantine cities through the transformation of baths and bath-gymnasium complexes. Within the scope of the examination, it is questioned how the transformation occurred in these structures and what the new function is.

In this direction, the transformations of the baths and bath-gymnasium complexes in Aizanoi, Amorium, Aphrodisias, Arykanda, Assos, Elaiussa Sebaste, Ephesos, Hierapolis, Miletos, Myra-Andriake, Olympos, Patara, Priene, Rhodiapolis, Sagalassos, Sardes Side and Tralleis are examined. These buildings, which cover a wide area in the city for functional reasons, are the examples that continue their original function, as well as the transformations after they lost their original function and were taken out of use, using a part of the building or the remaining land. As a result of the archaeological excavations, it has been determined that baths and bath-gymnasium complexes have different uses for residential, industrial, defense and administrative purposes, as well as for religious transformation. It is noteworthy that factors such as the change in a religious organization, the inadequacy of land as a result of the narrowing of the urban area and the development of economic life in new environments, played a role in the transformation of these buildings.

Keywords - Late Antiquity and Byzantine city, bath, bath-gymnasium complex, transformation 


\section{Giriș}

Antik çağda kentin, ekonomik, toplumsal, kültürel, siyasal ve dinsel işlevleri kentteki kamu yapılarına ve bunların kentsel konumlarına yansır. Yıkanma işlevi ile birlikte entelektüel bir boyuta sahip olan hamamlar ve hamam-gmnasium kompleksleri de kentin önemli bir konumundadir.

Roma Dönemi boyunca hamamlar, kent kültürünün önemli bir unsuru olarak kalmış, gündelik ve sosyal ilişki merkezleri olarak işlev görmüştür. ${ }^{1}$ Hamamlar, Roma İmparatorluğu'ndaki kent yaşamının en önemli belirtilerinden biridir. Vatandaşlar bu yapılarda, egzersiz yapabilir, rahatlar, arkadaşlarla tanışabilir ve siyasi, entelektüel veya ticari konular hakkında sohbet edebilir. ${ }^{2}$

Hamam-gymasium kompleksleri ise boyut ve görkemlilik bakımından batıdaki imparatorluk hamamları ile karşılaştırılabilir. Bu yapısal formun oluşumunda ve gelişiminde Anadolu özel bir konuma sahiptir. Kompleks hem Roma hamamlarının yıkanma birimlerini içerir hem de bu hamamlara uyarlanan geniş ve sütun dizileriyle çevrili palaestraya sahiptir. Burada, çeşitli kültürel katmanlardan gelen kentli nüfusun eğitim, spor etkinlikleri ve kültürel gereksinimlerine cevap verilmektedir. ${ }^{3}$

Hamamlar, Bizans'ta işleyişini hiçbir zaman tamamen kesmemişse de dini metinler yıkanmayı reddetmiştir. ${ }^{4}$ Ancak din adamları ve rahipler bile, bazen Hıristiyan ikonografisinden konularla süslenmiş olan hamamları kullanmışlardır. Örneğin Konstantinopolis piskoposu Sissinius ${ }^{5}$ 'un günde üç kez banyo yapmasına izin verilmediğinden günde iki kez banyo yaptığ 1 belirtilmektedir. Ayrıca İoannis Hrisostomos ${ }^{6}$, Theodosius'un Antakya'daki hamamların kapatılmasını emretmesinin ardından eski ve gerekli bir gelenek olduğu için yıkanmanın yokluğunun yıkıcı olduğunu not etmiştir.? Bununla birlikte kilise, hamamları ahlaksızlık merkezleri olarak görmüş, karma hamamları yasaklayan düzenlemeler yayınlamış ve din adamlarının hamamlara yaptığı ziyaretleri kınamıștır. Hamamlar, Antik Çăg'da olduğu gibi sosyal yaşama odaklanmamış; 6. yüzyıldan sonra sadece özel bir faaliyet haline gelmiştir. ${ }^{9}$

Ancak Geç Antik Çağ boyunca hamamların büyük ölçüde işlevlerini devam ettirdiği belirtilebilir. Prokopius da De Aedificiis'de hamamları, müreffeh bir kentin simge yapıları arasında saymaktadır. ${ }^{10} 4$. yüzyıldan itibaren, hamamların mimari tasarımında değişiklikler gözlemlenir. Hamamlardaki çoğu büyük ortak havuz, daha küçük parçalara bölünür. Bununla birlikte, birçok imparator 6 . yüzyılın ortalarına kadar yeni hamamlar inșa ettirir ya da eskilerinin onarımını yaptırır. Kentler de hamamları dikkatli bir șekilde korumuştur. Arkeolojik kanıtlar, 6. yüzyılın ortaları ile ilgili bir değişiklik olduğunu gösterir. ${ }^{11}$ Büyük kamu hamamlarının çoğu ya nüfusun azalmasından dolayı ya da sadece çok pahalıya mal olduklarından dolayı kullanılmazlar. Bazıları yok edilir, diğerleri ise kilise, konut gibi yapılara dönüştürülür. Bazı kamu hamamları büyük şehirlerde çalışmaya devam eder, ancak halkın hamamlara ve yıkanmaya olan genel tutumu yavaş yavaş değişir. ${ }^{12}$ Konstantinopolis'teki büyük hamamlar bile 7. ve 8. yüzyıllar boyunca

${ }^{1}$ Alexander P. Kazhdan, The Oxford Dictionary of Byzantium (Cilt 1), Oxford University Press, Oxford, 1991, s. 271

2 Helen Saradi-Mendelovici, "The Demise of the Ancient City and the Emergence of the Mediaeval City in the Eastern Roman Empire", Echos du monde classique: Classical Views, 32 (3), 1988, s. 382.

${ }^{3}$ Fikret Yegül, Antik Çağ'da Hamamlar ve Yikanma, (Çev: Emel Erten), Homer Kitabevi, İstanbul, 2006, s. 216.

${ }^{4}$ Saradi-Mendelovici, "The Demise of...", s. 383.

5 II Sisinnius 996'da Konstantinopolis Ekümenik Patriği olmuș ve 998'deki ölümüne kadar görevde kalmıştır.

6 349'da Antakya'da doğmuştur. 397'de I. Theodosius tarafindan Konstantinopolis Patriği olarak atanmıştır. 407'de ölmüştür.

${ }^{7}$ Helen G. Saradi, The Byzantine City in the Sixth Century: Literary Images and Historical Reality, Society of Messenian Archaeological Studies, Athens, 2006, 327. ortadan kaybolur. Böylelikle başkentte halk hamamı sayıs1 azalır, hatta eyaletlerde daha da düşüş gösterir. Özel hamamlar diğerlerine göre daha fazla önem kazanır ${ }^{13}$.

Hamamlara katılım, artık günlük yaşamın normal bir parçası değil, ancak lüks ya da hijyenik bir gereklilik haline gelir. Ayrıca hamamlar iyileşme ile ilişkilendirilir. Hasta rahipler ya da rahibeler ile manastır hastanelerindeki hastalara daha sık hatta sınırsız yıkanma için izin verilir. ${ }^{14}$ Dolayısıyla kentsel yaşamdaki değişiklikler hamamların görünümünün de değişmeye başladığını gösterir.

\section{Materyal ve Yöntem}

Moudon'a göre kentsel form, onu meydana getiren unsurların zaman içerisinde uğradıkları tarihsel dönüşüm ve değişimin ortaya koyulması ile anlaşılabilir. ${ }^{15} \mathrm{Bu}$ ilke doğrultusunda Bizans kentinin varlığını sürdürdüğü süreç boyunca geçirdiği dönüşüm hamamlar ve hamam-gymnasium yapıları üzerinden ortaya koyulmaya çalışılmıştır. Bu araştırmada mimari anlamda dönüşüm, zaman içinde değişen toplumsal, ekonomik, kültürel, dinsel ve siyasal koşullar üzerinden kentsel alanların ya da yapıların gerekli mimari uygulamalar ile özgün işlevinden farklı bir işlev yüklenmesi ve Bizans kent morfolojisi kapsamında yeniden kullanımı yönünde analiz edilmiştir. $\mathrm{Bu}$ doğrultuda hamamlarda meydana gelen dönüşümün nasıl oluştuğu ve sonucunda yeni işlevin ne olduğu sorgulanmaktadir

Çalışmanın ana kaynağını arkeolojik kazılar sonucu elde edilmiş veriler oluşturmaktadır. Çalışmada hamamların seçiminde, coğrafi bakımdan yerleşimlerin yoğun olarak yer alması, bunların önemli bir bölümünün kökenlerinin Antik Çağ’a dayanması ve dönemsel olarak yoğun nüfusun bulunması nedeniyle Anadolu'nun batısında ve güneybatısında yer alan kentler dikkate alınmıștır. Bu kapsamda değerlendirme, kıyıda ve kıyıya yakın kentlerden Assos, Elaiussa Sebaste, Ephesos, Miletos, Myra-Andriake, Olympos, Patara, Priene, Rhodiapolis ve Side'nin yanı sıra, bölgenin iç kısımlarında bulunan Aizanoi, Amorium, Aphrodisias, Arykanda, Hierapolis, Sagalassos, Sardes ve Tralleis kentlerinde yer alan hamamlar ve hamamgymnasium kompleksleri üzerinden yapılmıştır.

\section{Hamamlarda ve Hamam-Gymnasium Komplekslerinde İşlevin Devamlılı̆̆}

Kamu tesislerinin başında gelen hamamların kullanımının Geç Antik Çağ boyunca sürdüğü kanıtlanmıştır. 5. yüzyılın ilk çeyreğinde, hamamlarda genel bir yenileme gerçekleșmiștir. ${ }^{16} \mathrm{Bu}$ durumu ortaya koyan örnekler Ephesos, Sardes, Sagalassos, Miletos, Aphrodisias, Myra'nın liman yerleşimi Andriake, Olympos, Side, Arykanda, Patara ve Priene kentlerinde görülebilmektedir.

Ephesos Vedius Gymnasiumu, tüm büyük kamu hamamlarının, özellikle hamam-gymnasium komplekslerinin Geç Roma Dönemi'nin başlarında çalışmayı bırakmadığını göstermektedir. Ayrıca devlet dini olarak Hıristiyanlığın benimsenmesinin gelenek olarak umumi yıkanma özelliğini sona erdirmediğini de kanıtlamaktadır. Kamuya açık bu hamamda 5. yüzyılın başlarında,

${ }^{8}$ Cyril Mango, "Daily Life in Byzantium", Jahrbuch der Österreichischen Byzantinistik, 30, 1981, s. 338

9 Saradi-Mendelovici, "The Demise of...", s. 383.

${ }^{10}$ Procopius, The Buildings, (Çev: Henry Bronson Dewing), Loeb Classical Library, 1940, 336.

${ }^{11}$ Saradi-Mendelovici, "The Demise of...", s. 383

${ }^{12}$ Kazhdan, "The Oxford Dictionary..." s. 271.

${ }^{13}$ Saradi-Mendelovici, "The Demise of...,", s. 383

${ }^{14}$ Kazhdan, "The Oxford Dictionary..." s. 271.

15 Anne Vernez Moudon, "Urban Morphology as an Emerging Interdisciplinary Field", Urban Morphology, 1, 1997, s. 7.

${ }^{16}$ Sabine Ladstätter \& Andrea Pülz, "Ephesus in the Late Roman and Early Byzantine Period: Changes in its Urban Character from the Third to the Seventh Century ad", The Transition to Late Antiquity, on the Danube and Beyond, (Ed: Andrew Poulter), Oxford University Press, Oxford, 2007, s. 402. 
yeni bir donanımın yapıldığı bir evre gözlenmektedir. Bu dönemde ne oda sayısı azaltılmış ne de kompleksin herhangi bir bölümü terk edilmiştir. Yıkanma ile ilgili tesisatlar ise 5. yüzyılın sonuna kadar kullanılmaya devam edilmiştir. Geç Antik Çağ'da, en azından belirli toplum düzeyleri için klasik yaşam biçiminin bir ifadesi olarak hamamları ziyaret etmek cazibesini korumaya devam etmiştir. ${ }^{17}$ Yapının kullanımına son veren yıkım ise 6 . yüzyılın sonlarındadır. ${ }^{18}$ Pişirme kapları ve amforalar, konutlara ait işgalin bu antik kamu tesisini kısmen devraldığını ve muhtemelen 6 . yüzyılın sonlarına doğru çatı çökene kadar sürdüğünü göstermektedir. ${ }^{19}$

Geç Roma ve Erken Bizans Dönemi'nde Sardes hamam-gymnasium kompleksi ise birkaç kez restore edilerek 6. yüzy1lda hamam ve sivil buluşma yeri olarak işlev görmeye devam etmiştir. ${ }^{20}$

120-165 yılları arasında inşa edilen Sagalassos İmparatorluk Hamamı'nda da (hamam-gymnasium kompleksi) 4. yüzyılın sonunda, hamamın sadece dekorasyonunu değil aynı zamanda iç işlev sıralamasını da değiştiren geniş çaplı bir yenileme çalışması gerçekleştirilmiştir. 6. yüzyılın ikinci ve üçüncü çeyreğinden itibaren Roma Hamamı'nın bazı kısımlarının söküldüğü izlenir. Ayrıca palaestranın güney kesimindeki çeşitli katmanlardan yapının 7 . yüzyılda büyük bir depremden önemli şekilde etkilenmiş olduğu belirtilmiştir. ${ }^{21}$

Miletos'ta da 1. yüzyılın sonlarından kalan Güney Hamamları, 5. yüzyılın sonlarında ya da ondan sonra, kompleksin ikiye, muhtemelen erkek ve kadın olarak- ayrıldığı zaman büyük ölçüde yenilenmiştir. ${ }^{22}$

Aphrodisias'ta Hadrianus Hamamları'nın 6. yüzyıla kadar kullanılmış olduğu belirtilmektedir. ${ }^{23} 5$. yüzyılın sonlarından itibaren Hadrian ve Tiyatro Hamamları'nın tadilatı ve dönüştürülmesi ile kuzey ve güney agoralar gibi kamusal alanların süslenmesi kentte ikinci bir canlanma evresini oluşturmuş̧ur. ${ }^{24}$

Myra'nın limanı Andriake'de yer alan Doğu Hamamı, Geç RomaErken Bizans Dönemleri'ne tarihlenmiş, Roma evresindeki yan yana sıralanan üç mekânlı yapı, Bizans Dönemi'nde değiştirilmiş ve yeni bir caldarium eklenerek planı değiştirilmiştir. Yapı, Bizans Dönemi değişikliğiyle 5.-6. yüzyılda kullanılmaya devam etmiş, 7. yüzyıl başına kadar onarımlarla işlevini sürdürmüştür. ${ }^{25}$

Olympos güney kentin Roma Dönemi'ne ait en anıtsal yapısı olan Vespasian Dönemi hamamı, Bizans Dönemi’nde de kullanılmıştır. Ana mekânda yapının genel plan özellikleri ile örtüşmeyen bir takım değişikliklere gidilmiştir. Yapının kuzey kanadında yer alan apsisli küçük mekânlar Bizans Dönemi'nin erken safhalarında hamamın

\footnotetext{
${ }^{17}$ Ladstätter \& Pülz, "Ephesus in the Late Roman...”, s. 402.

${ }^{18}$ Sabine Ladstätter, "Bizans Dönemi’nde Ephesos: Büyük Bir Antik Kentin Tarihinde Son Sayfa", Bizans Dönemi'nde Ephesos, (Ed: Falko Daim \& Sabine Ladstätter), Ege Yayınları, İstanbul, 2011, s. 13.

${ }^{19}$ Ladstätter \& Pülz, "Ephesus in the Late Roman...", s. 402.

${ }^{20}$ Fikret Yegül, The Bath-Gymnasium Complex at Sardis, Harvard University

Press, Cambridge, 1986, s. 5-16.

${ }^{21}$ Jeroen Poblome, Ebru Torun, Peter Talloen, Inge Uytterhoeven, Hendrik Uleners, Johan Claeys, Roel Van Beeumen, Semih Ercan \& Hacı Ali Ekinci, "Sagalassos'ta 2014 Yılı Kazı ve Restorasyon Çalışmaları", 37. Kaz Sonuçları Toplantısı, Cilt 3, T.C. Kültür ve Turizm Bakanlığı Yayınları, Ankara, 2016, s. 88-89.

${ }^{22}$ Philipp Niewöhner, "Miletus", The Archaeology of Byzantine Anatolia: From the End of Late Antiquity until the Coming of the Turks, (Ed: Philipp Niewöhner), Oxford University Press, New York, 2017, s. 257.

${ }^{23}$ Erdal Yazıcı, Aphrodisias ve Çevresi, Uranus Yayınevi, İstanbul, 2015, s. 49.

${ }^{24}$ Örgü Dalgıç \& Alexander Sokolicek, “Aphrodisias”, The Archaeology of Byzantine Anatolia: From the End of Late Antiquity until the Coming of the Turks, (Ed: Philipp Niewöhner), Oxford University Press, New York, 2017, s. 273.

${ }^{25}$ Nevzat Çevik \& Süleyman Bulut, "Andriake Doğu Hamamı: Bölgenin Hamam Mimarlığına Işık Tutan Yeni Bir Örnek”, Adalya, XVII, 2014, s. 239;
}

küçülerek de olsa aynı işlevle kullanılmaya devam ettiğini düşündürmektedir. Söz konusu değişikliklerde inşa edilen duvarların malzeme, teknik ve kalınlıklar açısından Olympos'un Bizans Dönemi yapıları ile örtüşüyor olması bu kanıyı desteklemektedir. ${ }^{26}$ Kuzey Kent'in doğusunda, kent girişine yakın bir konumda yer alan Liman Hamamı da Bizans Dönemi'nde yine aynı işlevle kullanılmaya devam edilen diğer bir hamam yapısıdır. ${ }^{27}$

Side'nin en büyük hamamı olan -3. yüzyılda yapılmış ve 5.-6. yüzyıllarda onarım görmüş olan-Büyük Hamam da $^{28} \mathrm{Geç}$ Antik Dönem'de işlevin devamlılığını göstermesi adına önemlidir.

Arykanda'da 4. yüzyıl sonuna ait bir yapım evresi olan Yamaç Hamamı'nın 5. yüzyıl sonu ile 6. yüzyıl başında da kullanıldığı; işlevini 6. yüzyılın ortalarında yitirmiş olduğu görülmektedir. ${ }^{29}$ Patara'da ise Liman Hamamı'nın 4. yüzyılın sonu-5. yüzyılın başında hamam olarak kullanımının sona erdiği ve ayrıca kentin 6. yüzyılda hala kullanımda olan Nero Hamamları'nın da sura dahil edildiği ifade edilmektedir. ${ }^{30}$

Priene'de Yukarı Gymnasion'un bulunduğu arsanın kuzeybat köşesindeki yerden ısıtmalı ve derin havuzlu yapının da Bizans Dönemi'ne ait küçük bir hamam olabileceği belirtilir. ${ }^{31}$

Yukarıda bahsi geçen örneklerin yanı sıra Erken Bizans Dönemi'nde inşa edilen yeni hamam yapılarına da rastlanmaktadır. Hierapolis, Side ve Ephesos kentlerindeki yapımlar örnek olarak gösterilebilir. Hierapolis'te Erken Bizans Dönemi'nde iki yeni hamam yapısı inşa edilmiştir. Biri 4. yüzyıl depreminden sonra yıkılan agoranın güney stoas1 üzerinde yer alan ve 5. ya da 6. yüzyıla tarihlenen kent surlarının yanına inşa edilmiştir. 7. yüzyıl depremi binanın büyük bir bölümünde hasara yol açmış, yıkılmamış olan bölümü ise daha sonra yeniden kullanılmıştır. ${ }^{32}$ Diğeri ise Aziz Philippus Kutsal Alanı'nı ziyaret eden hacılar için yapılmıştır. 4. yüzyıl sonu-5. yüzyıl başına tarihlenen hamam sekizgen planlıdır (Şekil 1) ve içinde çeşitli büyüklüklerde mekânlar yer almaktadır. Yapının hemen hemen tüm mekânlarının özelliği apsisin içine yerleştirilmiş bireysel yıkanma için kullanılan havuzların yer almasıdır. ${ }^{33}$

Ephesos'ta ise tiyatronun kuzeydoğusunda dört apsis nişli dairesel yapı hamam olarak tanımlanmıştır (Şekil 2). Yapı bir suyolu üzerine inşa edilmiştir. Geç Antik/Erken Bizans Dönemi'ne tarihlendirilmiştir. Ancak ne kadar süreli kullanıldığına ilişkin bilgi bulunmamaktadır. ${ }^{34}$

Nevzat Çevik, Lykia Kitabı, Suna-İnan Kıraç Akdeniz Medeniyetleri Araștırma Enstitüsü, Antalya, 2015, s. 388.

${ }^{26}$ Yalçın Mergen, Olympos Antik Kenti'nin Orta Çă̆ Dönemi Dokusu ve Likya Bölgesi Açısından Önemi, Basılmamış Doktora Tezi, Ege Üniversitesi Sosyal Bilimler Enstitüsü, 2011, 283-284.

${ }^{27}$ Mergen, “Olympos Antik Kenti'nin...", s. 413-420.

${ }^{28}$ Orhan Atvur \& Ümit Atvur, Side, Aksoy Grafik Dizgi Matbaacılık, İstanbul, 1984, s. 32.

${ }^{29}$ Cevdet Bayburtluoğlu, Yüksek Kayalığın Yanındaki Yer: Arykanda, Homer Kitabevi, İstanbul, 2003, s. 134.

${ }^{30}$ Fahri Işı1k, Havva İşkan \& Nevzat Çevik, MILIARIUM LYCIAE: Patara Yol Kılavuz Anıtı / Das Wegweisermonument von Patara, Akdeniz Üniversitesi Yayınları, Antalya, 2001, s. 55.

31 Frank Rumscheid, Priene: Küçük Asya'nın Pompeisi Rehberi, Ege Yayınları, İstanbul, 2000, s. 185.

${ }^{32}$ Paul Arthur, Bizans ve Türk Dönemi'nde Hierapolis (Pamukkale), (Çev: N. Firat), Ege Yayınları, İstanbul, 2006, s. 145.

${ }^{33}$ Maria Piera Caggia, "Sekizgen Hamam”, Phrygia Hierapolisi Yeni Atlası. Kentin ve Nekropolislerin Arkeoloji Haritast, (Ed: Giuseppe Scardozzi), Ege Yayınları, İstanbul, 2015, s. 123.

${ }^{34}$ Martin Steskal, "Erken Bizans Döneminde Ephesos'ta Yıkanma ve Hamam

Mimarisi”, Bizans Dönemi'nde Ephesos, (Ed: Falko Daim \& Sabine Ladstätter), Ege Yayınları, İstanbul, 2011, s. 89. 


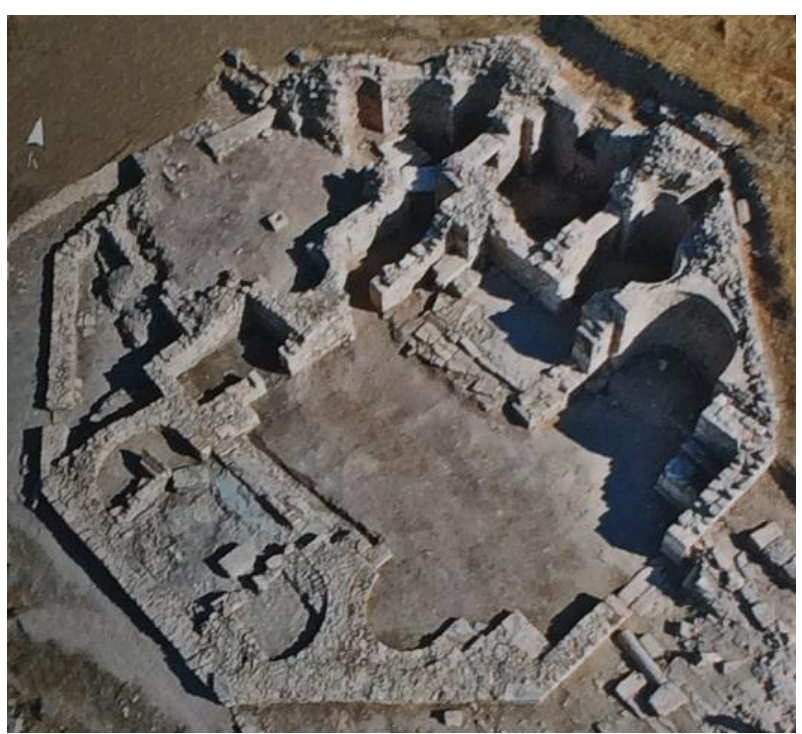

Şekil 1. Hierapolis, Sekizgen Hamam ${ }^{35}$

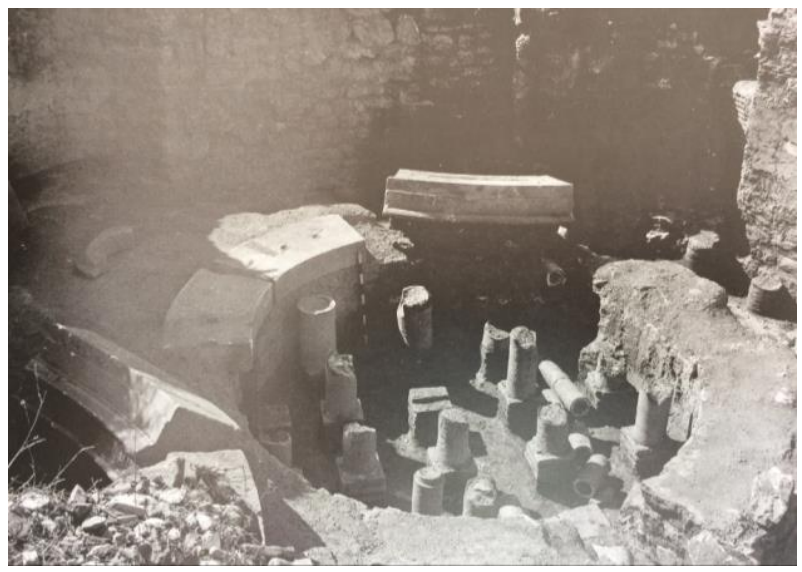

Şekil 2. Ephesos, tiyatronun kuzeydoğusundaki hamam ${ }^{36}$

Side kentinin olasılıkla sur dışına taştığı 5 . yüzyılda inşa edilen bir hamam yapısı (Agora Hamamı) Erken Bizans Dönemi'ndeki kamusal faaliyetlere örnek teşkil etmektedir. ${ }^{37}$ Side'nin tarih olarak en geç yapılmış hamamıdır.

Erken Bizans Dönemi'nde hamam yapılarının varlı̆̆ına ve işlevlerinin devamlılığına ilişkin kanıtların fazla olmasına rağmen Orta ve Geç Bizans Dönemleri'ne ait bilgiler kısıtlıdır. Ancak Amorium'da büyük olasılıkla 6. yüzyılda yapılmış, çokgen mekân ve dikdörtgen hamam bölümü olmak üzere iki bölümlü olarak tanımlanabilen kamusal bir kompleks bulunmaktadır. Çokgen yapının uzun süre kullanılmadığı anlaşılmaktadır. Yapının, 6 . yüzyılda Anadolu'yu sarsan depremler sonucunda büyük ölçüde tahribe uğradıktan sonra kullanım açısından tehlike yarattığı için terk edilmiş olabileceği belirtildiği gibi, 8. yüzyıldaki sosyal ve ekonomik baskılar nedeniyle kullanım dışı kalmış olabileceği de ifade edilmiştir. Ancak hamam odalarının yer aldığı dikdörtgen yapının

${ }^{35}$ Caggia, "Sekizgen Hamam", s. 123.

${ }^{36}$ Steskal, "Erken Bizans Döneminde...", s. 89.

${ }^{37}$ George E. Bean, Eskiçağda Güney Kıyılar, (Çev: İnci Delemen \& Sedef Çokay), Arion Yayınları, İstanbul, 1999, s. 72.

${ }^{38}$ Christopher Lightfoot \& Mücahide Lightfoot, Amorium Anadolu'da Bir Bizans Kenti, Homer Kitabevi, İstanbul, 2007, s. 131-133.

39 Christopher Lightfoot, "Amorium", The Archaeology of Byzantine Anatolia: From the End of Late Antiquity until the Coming of the Turks, (Ed: Philipp Niewöhner), Oxford University Press, New York, 2017, s. 335.

${ }^{40}$ Saradi-Mendelovici, "The Demise of...", s. 382-383.
Karanlık Çağ boyunca kullanılmaya devam edildiği, hamamın çeşitli

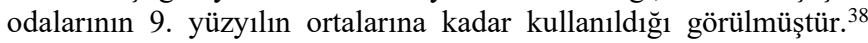
Hamam, hipokaust ve 1sıtmalı duvarlarla donatılmış, mermer kaplama ve zeminler ile zengin bir biçimde dekore edilmiştir. Yapı, mütevazi boyutuna rağmen, kamu kullanımı için tasarlanmıştır. ${ }^{39}$

\section{Hamamlarm ve Hamam-Gymnasium Komplekslerinin Dönüşümü}

Hıristiyanlığın ve dinsel örgütlenmenin etkinleşmesi ile Antik Çağ kültürüne ait hamamlar kısmen işlevini devam ettirse de yeni toplumsal yönelime uygun değişim göstermiştir. Antik hamamların kullanımına ilişkin din adamlarının ifadeleri dikkat çeker. Özellikle Aziz Pakhomios'un Manastır Hayatı Yönetmeliği'nin, tıbbi amaçlar hariç banyo yapmayı yasaklaması ile İskenderiyeli Clement'in, Hıristiyanları manevi hamamları tercih etmeye çağırması hamam kullanımlarının kısıtlanmasına atıf yapar. Tessalonike'nın ünlü metropoliti Eustathius'a göre ise banyo yapmak aptallığın bir göstergesidir. ${ }^{40} \mathrm{Bu}$ ifadelerden, Hıristiyan ahlakının yayılışı ile birlikte hamamların pagan geçmişe ait yapılar olarak kabul edildiği ve giderek daha az ziyaret edilerek işlevsizleştirildiği anlaşılabilir. 5.6. yüzyıllarda bu alanlarda giderek ibadethaneler, konut alanları, endüstriyel yapılar ve yönetim yapıları gözlenmektedir.

\section{Dinsel Dönüșümler}

Assos'ta bir hamam yapısı Erken Bizans Çağı'nda yeni bir düzenleme yapılarak başka bir amaç için kullanılmıştır. İlk kazılarda, hamam içerisinde apsis formlu duvar kalıntısı tespit edilmiştir. Bu nedenle Francis H. Bacon, hamamın bir kısmının kilise olarak kullanılmış olabileceğini ileri sürer (Şekil 3). Odalardan birinin kapı eşiğindeki yazıt hamamdaki ilavelerin MS 6. yüzyılda gerçekleştiğini göstermektedir. ${ }^{41}$

M.Ö. 2. yüzyılda inşa edilen Assos Gmnasiumu, Roma Dönemi'nde de kullanılmış olup Clarke ve Bacon gymnasiumdaki kazılarda, yapının doğu bölümünün kiliseye dönüştürüldüğ̈̈nü tespit etmiştir. ${ }^{42}$ Üç nefli ve bazilikal planlı kilise (Şekil 4), 41×22.5 metre boyutlarında olup, naosu 11 metre genişliğindedir. Yan nefler, naostan sekiz adet sütun ile ayrılmıştır. Gymnasiumun kuzeydoğu yönündeki revağının (portikos) sütunlarından faydalanılmıştır. Kilise, gerek mozaik gerekse mimari özelliklere göre, MS 5.-6. yüzyıla tarihlenmektedir. ${ }^{43}$ Serdaroğlu da kilisenin MS 6. yüzyılda inşa edildiğini belirtmektedir. ${ }^{44}$

Hierapolis'te de bir hamam yapısının Erken Bizans Dönemi'nde kiliseye dönüştürüldüğü görülmektedir. Hamam-Kilise olarak anılan yap1 3. yüzyılda inşa edilmiş olup olasılıkla 5. yüzyılın birinci yarısında, hamamın sıcaklık bölümü olan caldarium, dış cephedeki tipik mimarisiyle bir apsis ve beșik tonozlu çatı ya da pandantifli üç kubbenin eklenmesiyle kilisenin nefine dönüştürülmüştür (Şekil 5). 7. yüzyılın ortalarındaki deprem sonrası terk edilmiştir. ${ }^{45}$
${ }^{41}$ Nurettin Arslan \& Beate Böhlendorf Arslan, Taşın Hayat Verdiği Kent Assos, Homer Kitabevi, İstanbul, 2014, s. 97.

${ }^{42}$ Joseph Thacher Clarke, Francis H. Bacon, Robert Koldewey, Expedition of the Archaeological Institute of America, Investigations at Assos, Drawings and Photographs of the Buildings and Objects Discovered during the Excavations of 1881, 1882, 1883, Bernard Quaritch Henry Sotheran \& Co., London, 1902-1921, s. 183.

${ }^{43}$ Arslan \& Böhlendorf Arslan, "Taşın Hayat Verdiği...,", s. 142-143.

${ }^{44}$ Ümit Serdaroğlu, Assos Bahramkale, Arkeoloji ve Sanat Yayınları, İstanbul, 1995, s. 63.

${ }^{45}$ Arthur, "Bizans ve Türk Dönemi'nde...”, s. 100. 


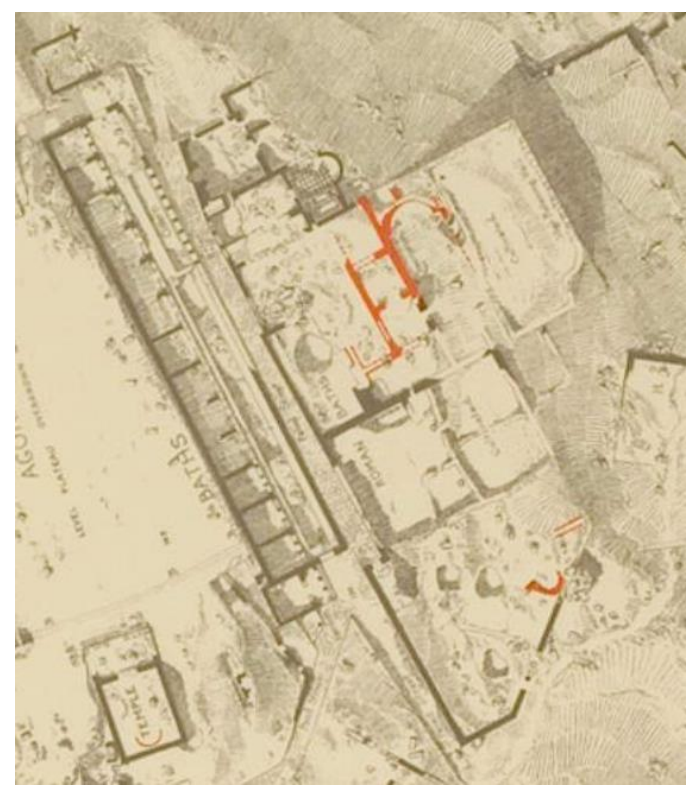

Şekil 3. Assos, hamam üzerindeki kilise plan1 ${ }^{46}$

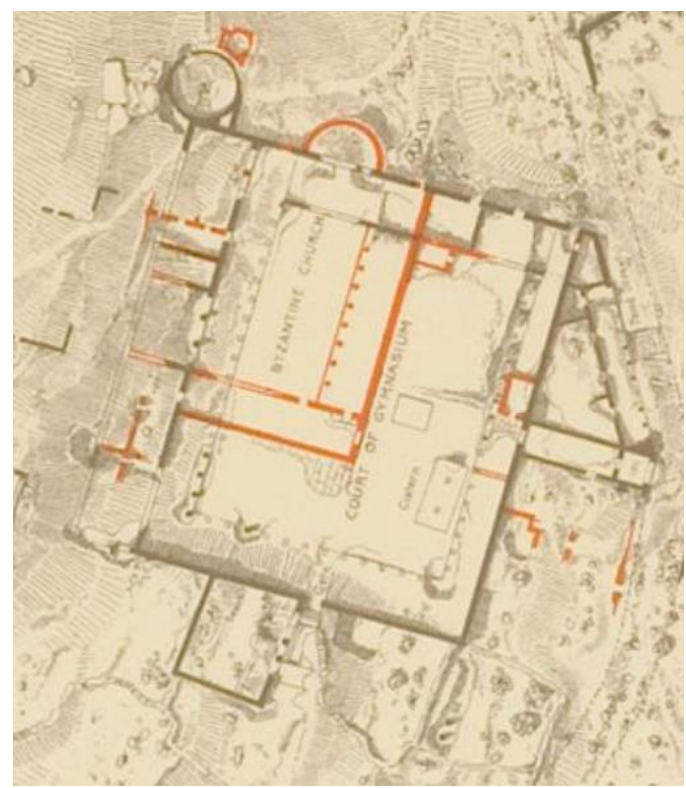

Şekil 4. Assos, Gymnasium Kilisesi planı ${ }^{47}$

Priene'de ise Yukarı Gymnasion'un bulunduğu arsanın kuzeybatı köşesinde konumlanan, Bizans Dönemi’ne ait küçük bir hamam olabileceği belirtilen yapı bir yangında yıkıldıktan sonra,

kalıntılarının batısına tiyatro kilisesinin güney nefinden ulaşılan küçük bir şapel inşa edilmiştir. ${ }^{48}$

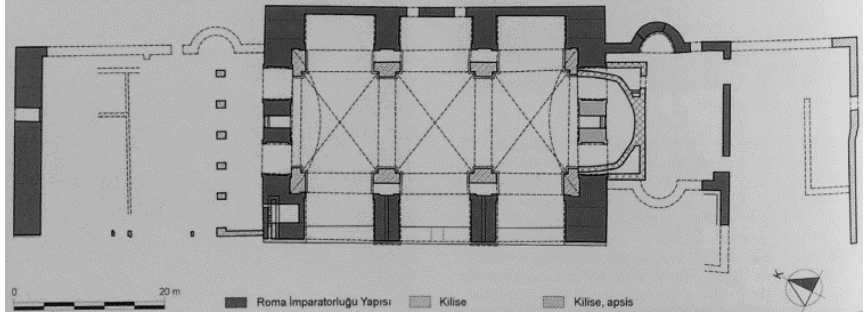

Şekil 5. Hierapolis Hamam-Kilise yap $1 \mathbf{s}^{49}$

Theodosius Hanedanlığı Dönemi'nde (379-457) Ephesos'ta, Doğu Gymnasium'da bir bazilika inşa edilmiştir. Yapının, kentin ilk piskoposluk bazilikası olabileceği yönünde bir öneri bulunmaktadır. 6. yüzyılın ilk yarısında ise mevcut kilisenin önemli ölçüde büyütülmesi veya yenilenmesi gerçekleşmiştir. ${ }^{50}$ Ephesos'daki kiliselerin çoğunluğunun önceden mevcut kamu binalarını (Doğu Gymnasiumu, Vedius Gymnasiumu, Liman Gymnasiumu) kullanmış olduğu söylenebilir. ${ }^{5}$

Diğer bir dönüşüm de Elaiussa-Sebaste'de Roma İmparatorluk yapısı olan büyük hamamda gerçekleşmiştir ${ }^{52}$. Yapının palaestra alanı üzerine bir bazilika inşa edilmiştir (Şekil 6). ${ }^{53}$ Ayrıca Aizanoi' de de 3. yüzyıla tarihlenmiş bir hamam yapısı 5. yüzyılda Erken Bizans Dönemi'nde liturjik ahşap malzemelerle büyük bir kilise kompleksine dönüştürülmüştür. ${ }^{54}$ Kilise erken dönem yapısının bütününü kullanmaktadır. ${ }^{55}$

\section{Konut Amaçıı Dönüșümler}

Ephesos Vedius Gymnasiumu'nun kullanımına son veren yıkım 6. yüzyılın sonlarındadır. Bu alan, çatılarının yıkılmasından sonra da basit konut amaçlı bir adaptasyon geçirmiş ve kullanılmıştır. Büyük olasılıkla bu yerleşim evresi 7.-9. yüzyıllara tarihlenmektedir. ${ }^{56}$ Ortaçağ' 1 erken dönemlerinde basit konutlar mevcudiyetini korumuştur. $^{57}$

Ephesos Liman Gymnasiumu'nun palaestrası gibi büyük avlu yapılar, zengin donanımlı konut alanlarını barındırmak için yeterli alan sunmuştur (Şekil 7). Bu konutlarda çok renkli mozaik tabanlı, opus sectile döșemeli ve duvar resimli peristilli evler söz konusudur. Evlerin 7. yüzyılın ortalarına kadar kullanıldığı belirtilmektedir. ${ }^{58}$
${ }^{46}$ Clarke, Bacon, \& Koldewey, "Expedition of the Archaeological...", s. 21.

${ }^{47}$ Clarke, Bacon, \& Koldewey, "Expedition of the Archaeological...", s. 21.

${ }^{48}$ Rumscheid, "Priene...", s. 185.

49 Francesco D’Andria, "Hamam-Kilise”, Phrygia Hierapolisi Yeni Atlast. Kentin ve Nekropolislerin Arkeoloji Haritast, (Ed: Giuseppe Scardozzi), Ege Yayınları, İstanbul, 2015, s. 96.

${ }^{50}$ Ladstätter \& Pülz, "Ephesus in the Late Roman...", s. 413-414.

${ }^{51}$ Ladstätter \& Pülz, "Ephesus in the Late Roman...", s. 416.

${ }^{52}$ Eugenia Equini Schneider, Doğu ile Batı Arasında Bir Liman Kenti Elaiussa Sebaste, Homer Kitabevi, İstanbul 2008, s. 70.

53 Eugenia Equini Schneider, "Elaiussa Sebaste: 2014 Excavation and Conservation Works", 37. Kazı Sonuçlart Toplantısı, Cilt 3, T.C. Kültür ve Turizm Bakanlığı Yayınları, Ankara, 2016, 479.
54 Rudolf Naumann, “Ausgrabungen In Aizanoi 1983”, 6. Kazı Sonuçlar Toplantısı, T.C. Kültür ve Turizm Bakanlığı Eski Eserler ve Müzeler Genel Müdürlüğü, İzmir, 1984, s. 380; Fabian Stroth, "Aezani”, The Archaeology of Byzantine Anatolia: From the End of Late Antiquity until the Coming of the Turks, (Ed: Philipp Niewöhner), Oxford University Press, New York, 2017, s. 328.

55 Burcu Ceylan, Batı Anadolu Bölgesinde Bulunan Antik Dönem Anttsal Yapılarından Dönüstürülmüs Bazilika Planlı Kiliseler, Basılmamıs Doktora Tezi, Hacettepe Üniversitesi Sosyal Bilimler Enstitüsü, 2000, 146.

${ }^{56}$ Ladstätter, "Bizans Döneminde Ephesos...", s. 13.

${ }^{57}$ Ladstätter \& Pülz, "Ephesus in the Late Roman...", s. 402

${ }^{58}$ Ladstätter, "Bizans Döneminde Ephesos...", s. 12; Andrea Pülz, "Bizans

Dönemi'nde Ephesos'un Görünümü”, Bizans Dönemi’nde Ephesos, (Ed Falko Daim \& Sabine Ladstätter), Ege Yayınları, İstanbul, 2011, s. 58. 


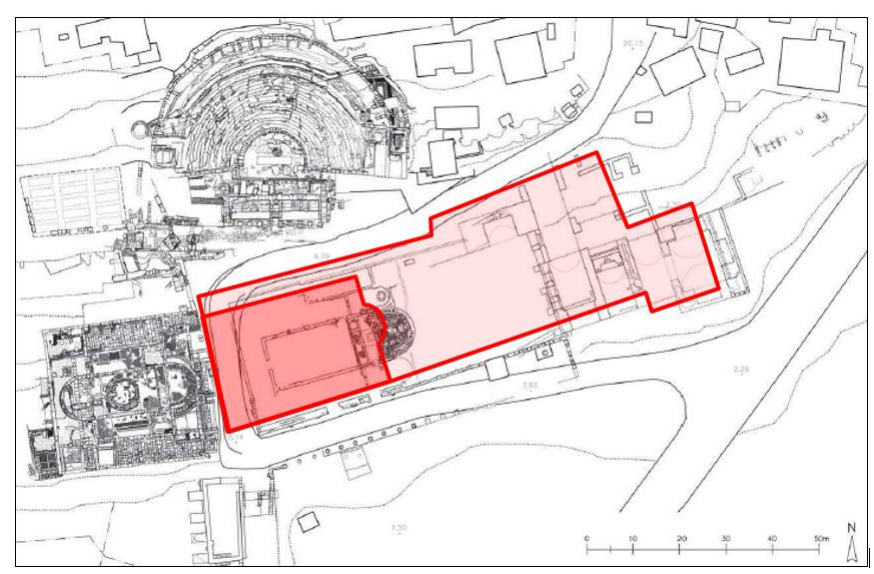

Şekil 6. Elaiussa Sebaste'de Büyük Hamam içindeki kilise ${ }^{59}$

Hierapolis'te 4. yüzyıl sonu-5. yüzyıl başında inşa edilen Aziz Philippus Kutsal Alanı'nı ziyaret eden hacılar için yapılmış hamam 7. yüzyılın ikinci yarısında gerçekleşen depremde hasar görmüş, Orta Bizans Dönemi'nde küçük konut mekânları olarak kullanılmıștır. ${ }^{60}$ Yine Hierapolis'te Büyük Yapı (Roma Dönemi'nde inşa edilmiş olup kazılar sonucu yapının işlevi hamam olarak belirlenmiştir) içinde 9.10. yüzyılda çok sayı1da konut inşa edilmiştir. ${ }^{61}$ Bununla birlikte Merkez Hamam'in da 11. yüzyılda yeniden düzenlenmiş olup (Şekil 8) Geç Bizans Dönemi'nde (12.-13. ve 14. yüzy1llarda) basit yapılardan oluşan bir konut yerleşimine sahip olduğu anlaşılmaktadır. ${ }^{2}$ 19. yüzyıl başlarında Hierapolis'i ziyaret eden Fellows, buranın saray olduğu düşüncesini dile getirmiştir. ${ }^{63} \mathrm{Geç}$ Bizans Dönemi'ne ait buluntuların zenginliği ve kalitesi göz önüne alındığında ve Hierapolis'in diğer yerlerinden gelen buluntularla kıyaslandığında, hamam yapısının kentin geç dönemleri için bir yönetim merkezi haline geldiği belirtilmektedir. ${ }^{64}$

Olympos'ta ise 4. yüzyıl veya öncesine ait olduğu belirtilen bir hamam yapısının 5. yüzyıl sonu-6. yüzyıl başında, özenli bir konut olacak şekilde planlanarak, tekrar inşa edildiği ifade edilmiştir. ${ }^{65}$

Rhodiapolis'te de MS 2. yüzyıla tarihlenen Büyük Hamam 3. ve 4. yüzyıllarda revizyon geçirmiş, son yapılaşması Bizans Dönemi'nde olmuştur. Bu dönemde hamamın hemen hemen tüm bölümleri farklı kotlarda değişik amaçlarla kullanılmıştır. Bizans Dönemi yapılaşması sadece hazır kapalı bölümlerin yeniden yapılanması ile değil aynı zamanda Roma malzemesiyle yeni bölümler inşa etmek biçiminde de gerçekleşmiştir. En güneydeki tonozlu palaestrada yan yana Bizans yapıları görülür. Bunlar konut ve işlik olarak organize edilmiştir. ${ }^{66}$

\section{Endüstriyel Dönüşümler}

Elaiussa Sebaste Liman Hamamı'nın (Küçük Hamam) arkeolojik kanıtlara dayanarak 3. yüzyılın sonu ile 4. yüzyıl başlangıcı arasında kullanımının büyük ölçüde sona erdiği; ancak tamamen terk edilmediği belirtilmektedir.

\footnotetext{
${ }^{59}$ Eugenia Equini Schneider, "Elaiussa Sebaste: 2011-2012 Excavation and Conservation Works", 35. Kazı Sonuçlart Toplantısı, Cilt 3, Muğla Sitk1 Koçman Üniversitesi Yayınları, Muğla, 2014, s. 420.

${ }^{60}$ Caggia, "Sekizgen Hamam", s. 123.

${ }^{61}$ Francesco D'Andria, "Hierapolis 2002 Yılı Araştırma ve Kazı Çalışmaları", 25. Kazı Sonuçları Toplantısı, Cilt 2, T.C. Kültür ve Turizm Bakanlığı, Ankara, 2004, s. 113.

62 Salim Y1lmaz, Denizli, "Hierapolis (Pamukkale) Antik Kenti Roma Hamamı Sondaj Kazısı ve Temizlik Çalışmaları”, IV. Müze Kurtarma Kazıları Semineri, Ankara Üniversitesi Basımevi, Ankara, 1994, s. 203.

${ }^{63}$ Charles Fellows, A Journal Written During an Excursion in Asia Minor, John Murray, London, 1838, s. 284.
}

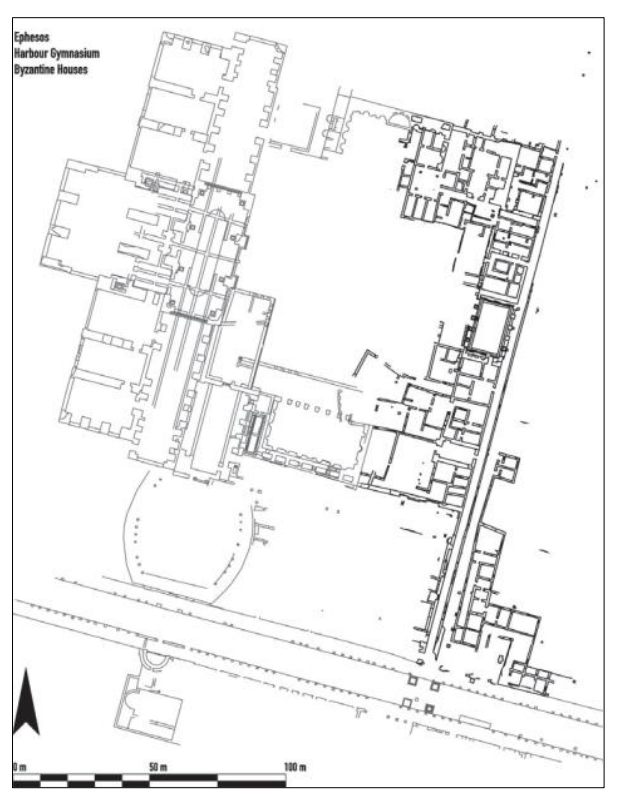

Şekil 7. Ephesos Liman Hamamı'nda Bizans konutlar ${ }^{67}$

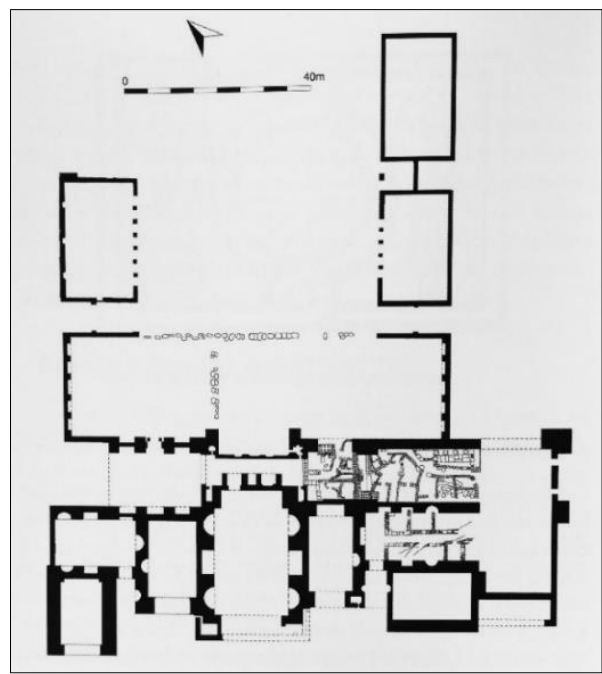

Şekil 8. Hierapolis Merkez Hamam'da 11. yüzyıl Bizans konutları ${ }^{68}$

Odalardan bazılarının kullanımı devam etmiş, bazılarından da 6 . yüzyılın sonu ve 7. yüzyılın başlangıcına dek çeşitli dönemlerde ustaların atölyeleri olarak ya da benzer amaçlarla yararlanılmıştır. Kazılar sonucunda gün 1şı̆̆ına çıkan buluntulara dayanarak, mekânların Bizans Dönemi'ndeki kullanımı saptanabilmektedir. Kullanımlar arasında zeytinyağı ya da un üretilen bir imalathane ile bronz lamina kesim işi sürdürülmüş bir mekân yer almaktadır. ${ }^{69}$

Tralleis kentinde MS 4. yüzyılda yaşanan siyasal ve toplumsal değişimler sonucunda gymnasium kapatılmıştır. $\mathrm{Bu}$ oluşum nedeniyle hamam yapısı güneye doğru genişletilerek büyük bir alanı

${ }^{64}$ Arthur, "Bizans ve Türk Dönemi'nde...”, s. 161.

${ }^{65}$ Gökçen K. Öztaşkın, Muradiye Öztaşkın, "Antalya-Olympos Mozaikli Yapı", Uluslararası Genç Bilimciler Buluşması I: Anadolu Akdenizi Sетровуити, Antalya, 2009, s. 335.

${ }^{66}$ Nevzat Çelik, "Rhodiapolis ve Kumluca Sınırlarındaki Diğer Antik Yerleşimler", Arkeolojisi, Tarihi, Doğası ve Tarımıyla Kumluca Rhodiapolis, (Ed: Nevzat Çelik), Kumluca Belediyesi Yayınları, Antalya, 2008, s. 22.

${ }^{67}$ Johannes Koder \& Sabine Ladstätter, "Ephesos, 2009”, 32. Kazı Sonuçları Toplantısı, Cilt 2, T.C. Kültür ve Turizm Bakanlığı Yayınları, Ankara, 2011, s. 293.

${ }^{68}$ Arthur, "Bizans ve Türk Dönemi'nde...", s. 160.

${ }^{69}$ Schneider, "Doğu ile Batı Arasında...", s. 88-89. 
kaplamış ve gymnasium içinde yapı faaliyetleri başlatılarak gymnasiuma farklı bölümler eklenmiştir. Gymansiumun batısında yer alan kuzey-güney doğrultulu 13 dükkan MS 4. yüzyıldaki yapım faaliyetlerinde eklenmiştir (Şekil 9). Elde edilen buluntular bu yapıların dokuma ve seramik sektörüyle ilgili olduğunu göstermektedir. ${ }^{70} \mathrm{Geç} \mathrm{Bizans} \mathrm{Dönemi'nde} \mathrm{ise} \mathrm{büyük} \mathrm{mimari} \mathrm{mermer}$ aksamlar yapılardan sökülüp, şehrin savunmasını güçlendirmek için yapılan sur sisteminde kullanılmak üzere yakılarak kirece dönüştürülmüştür. Gymnasiumun batısındaki çalışmalarda bu ocakların ortaya çıkması bunu doğrulamaktadır. Geç Bizans Dönemi'nde yapı bir savunma birimi olarak kullanılması nedeniyle dış duvarları güçlendirilerek bir kale konumuna bürünmüştür. ${ }^{71}$

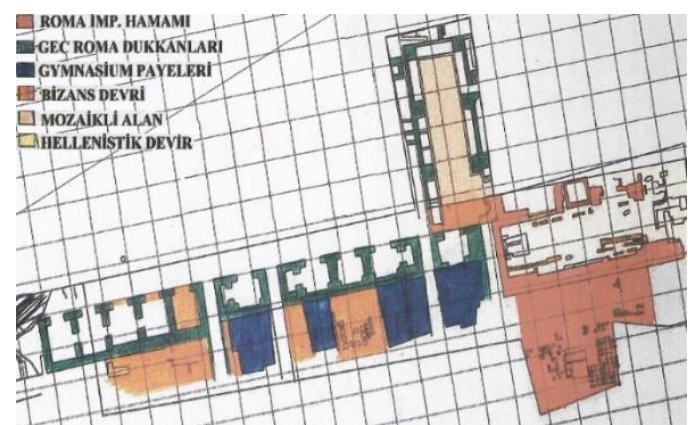

Şekil 9. Tralleis’te gymansiumun batısında yer alan dükkânlar ${ }^{72}$

Patara Liman Hamamı, Bizans Dönemi'nde çoğu Lykia hamamında olduğu gibi, işlik ve dükkânlara dönüşmüştür. ${ }^{73}$ Liman Hamamı'nın batı yüzünde, duvarlarla çevrili, içerisinde bir küp firını, tezgahı, duvara monte edilmiş çeşme ve havuzcuğu ile Bizans Dönemi'ne ait bir döküm işliği yer almaktadır (Şekil 10). İçerisinden küçük ve az sayıda cüruf çıkması fırının demir filizi değil, ikinci kez şekillendirmek üzere metal eşyaları eritmede kullanıldığını göstermiş̧iri. ${ }^{74}$ Her biri bağımsız bu mekânlar, hamamdan taşıma yassı tuğlalarla döşenmiş olup nitelikli tuğla örgüsü ve tonoz işçiliği, 6.yüzyıla ithaf edilmiştir. ${ }^{75}$ Liman Hamamı'nın 4. yüzyılın sonu-5. yüzyılın başında hamam olarak kullanımının sona ermesiyle birlikte 7. yüzyılın ilk yarısına kadar işlik alanı olarak kullanılmış olduğu belirtilmiştir. $^{76}$

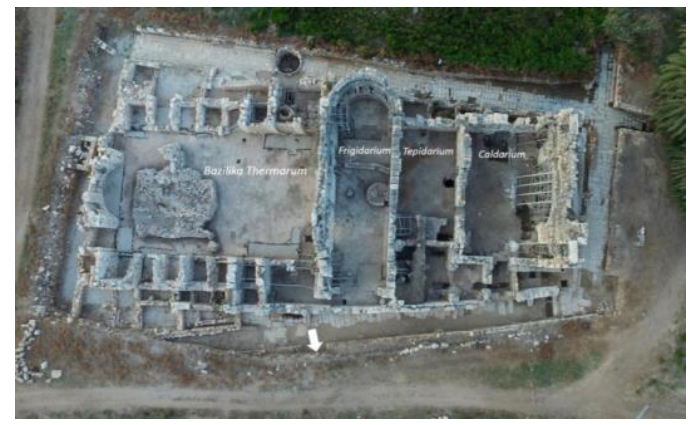

Şekil 10. Patara Liman Hamamı'nda derin nişlerde yer alan işlikler ${ }^{77}$

\section{Yönetimsel Dönüș̈umler}

\footnotetext{
${ }^{70}$ Rafet Dinç, Tralleis, Arkeoloji ve Sanat Yayınları, İstanbul, 2003, s. 33; 17 Rafet Dinç \& Erkan Dede, "Tralleis 1999 Kazısı Sonuç Raporu", Arkeoloji ve Sanat Dergisi, 114, 2003, s. 12.

${ }^{71}$ Dinç, "Tralleis", s. 33.

72 Dinç, "Tralleis", s. 34.

${ }^{73}$ Çevik, "Lykia Kitabı", s. 226.

${ }^{74}$ Fahri Işı1k, "Patara 1992", XV. Kazı Sonuçları Toplantısı, Cilt 2, Ankara Üniversitesi Basımevi, Ankara, 1995, s. 286.

${ }^{75}$ Fahri Işı1k, "Patara 1994", XVII. Kazı Sonuçları Toplantısı, Cilt 2, T.C. Kültür Bakanlığı Milli Kütüphane, Ankara, 1996, s. 165.
}

Side'de Piskoposluk kilisenin güneyinde yaşam ve idari işlevli olması gereken ve birbirine bitişik ve geçişli olarak düzenlenmiş mekânlardan oluşan bölüm yer almaktadır. Kalın duvarlı ve beşik tonoz örtülü olan bu bölümün, daha erken tarihli bir hamam yapısının Bizans Dönemi'nde farklı bir amaçla yeniden düzenlenmesiyle saraya dönüştürülmüş olabileceği belirtilmiştir. ${ }^{78}$

Priene'de de tiyatro yakınındaki bazilikanın güneyindeki bitişik Bizans yapı kompleksi küçük parçalı Bizans Dönemi Priene konut mimarisinden farklılık göstermektedir. Bazilikaya doğrudan açılan ve mimari açıdan vurgulanmış girişi, yapının özel ve olası resmi işlevine işaret etmektedir. Yapı, doğusundaki komşu eski gymnasion alanını kullanmıștır. ${ }^{79}$

\section{Değerlendirme ve Sonuç}

Erken Bizans Dönemi'nde hamam yapılarının varlığına ve işlevlerinin devamlılı̆̆ına ilişkin kanıtların fazla olmasına rağmen Orta ve Geç Bizans Dönemleri'ne ait bilgiler kısıtlıdır. Hamamlar ve hamam-gymnasium kompleksleri, Roma Dönemi'nin sona ermesiyle dini ve kültürel anlamda köklü değişikler içerisine giren kentlerde zamansal ve düşünsel değişimin mekâna yansıdığı önemli kentsel alanlar arasındadır. Bulgular 1şı̆̆ında, Bizans çağının erken dönemlerinde bu kentsel alanların işlevini devam ettiren örnekleri bulunmakla birlikte bazı örneklerin gereksinime uygun olarak yeni işlevler yüklenmesi sonucu dönüşüm geçirdiği görülmektedir. Hamamların Antik Çağ'da kaplamıș olduğu kentsel arazilerin kilise ve şapel, konut, dükkân ve işlik, sarayın bir bölümü ve hatta savunma sisteminin bir parçası olarak yeniden kullanılmış olduğu ifade edilebilir. Özellikle Geç Antik Dönem'de başlamıs olan kentsel dönüşümler Orta ve Geç Bizans Dönemleri’nde devam etmiştir.

Söz konusu dönüşümün temel faktörleri arasında Kilisenin 4. yüzyılın başlarından itibaren saldırdığı kent kurumları arasında hamamların da yer alması olmuştur. Çünkü bu kurumların pagan dini ile ilgili oldukları ve dolayısıyla Hıristiyan ahlakı ve ideolojisi ile bağdaşmadığı belirtilmiştir. ${ }^{80}$

Büyük Konstantinos Dönemi'nde (324-337) benimsenen Hıristiyanlığın yayılma döneminde dinsel organizasyonun kentlerde hiyerarşik biçimde yapılandırıldığı bilinmektedir. Anadolu'nun 5. ve 6. yüzyıllarında, erken Hıristiyan kentlerindeki en belirgin strüktürel değişim kiliselerin sayıca çoğalması ile gözlenir. Bu kapsamda yeni inșa edilen kiliselerin yanı sıra, antik yapılardan dönüștürülen kiliselerin de varlığı dikkat çekmektedir. Antik kentte geniş alanlara yayılan hamam ve hamam-gymnasium yapıları, kentlerdeki dinsel dönüşüm kapsamında yeniden işlev verilen yapılar arasına dahil olur. Aizanoi, Assos, Elaiussa-Sebaste, Ephesos, Hierapolis ve Priene kentlerinde hamam arazisinin bir bölümü üzerinde kilise ve şapel inşası gerçekleştirilir.

Mango, azalan nüfusun büyük ölçekli hamam yapılarından vazgeçilmesinde bir etken olduğunu belirtir. ${ }^{81}$ Dolayısıyla kentlerdeki nüfus değişimleri ve kentsel çevrenin sınırlı olanakları hamam ve hamam-gymnasium arazilerinin yeniden kullanımına yansır. Söz konusu yapıların kapladıkları geniş alanlar yeni konut ihtiyaçlarına cevap verebilecek alanlar olarak değerlendirilir. Geç Antik Çağ'dan Geç Bizans Dönemi'ne kadar geniş zaman dilimi içerisinde dönüşümler gerçekleşmiştir. Ephesos, Hierapolis,

${ }^{76}$ Serap Erkoç, "Patara Liman Hamamı: Mimarisi ve Yapı Evrelerine Dair İlk Gözlemler”, Phaselis Disiplinlerarası Akdeniz Araştırmaları Dergisi, 4, 2018, s. 255.

${ }^{77}$ Erkoç, "Patara Liman Hamamı...", s. 242

${ }^{78}$ Hüseyin Sabri Alanyalı, "Side 2011 Yılı Calıșmaları", 34. Kazı Sonuçları Toplantısı, Cilt 3, Pegasus Görsel İletişim Hizmetleri, Çorum, 2013, s. 209.

${ }^{79}$ Wulf Raeck \& Frank Rumscheid, "Die Arbeiten in Priene im Jahre 2009",

32. Kazı Sonuçları Toplantısı, Cilt 3, T.C. Kültür ve Turizm Bakanlığı

Yayınlar1, Ankara, 2011, s. 71.

${ }^{80}$ Saradi-Mendelovici, "The Demise of...", s. 377.

${ }^{81}$ Mango, "Daily Life...," s. 352. 
Olympos ve Rhodiapolis gibi yerleşimlerde konut amaçlı dönüşümler gözlemlenmektedir.

Endüstriyel faaliyetlerin kent içinde yer alması da hamamların dönüşümünü etkiler. Endüstriyel dönüşümler özellikle Geç Antik Çağ'da Elaiussa-Sebaste, Patara ve Tralleis gibi kentlerde gözlemlenebilmektedir.

Yönetimsel amaçlı dönüşümler de Side ve Priene gibi kentlerde görülmektedir. Bu kentlerdeki dönüşüm olasılıklar üzerine kuruludur ve yönetim yapıları antik yapıların bir bölümünü işgal etmiş görünmektedir.

Tralleis kentinde ise gymnasium yapısı Geç Bizans Dönemi'nde bir savunma birimi olarak kullanılması nedeniyle dıș duvarları güçlendirilerek bir kale konumuna bürünmüştür.

Dönüşümün önemli bir diğer nedeni ise ekonomik etkendir. Bu büyük yapıların 1sıtılması ve bakımının ağır bir ekonomik yük getirmesi de terk edilme nedenleri arasındadır. ${ }^{82}$ Antik Dönem yapılarının işlevlerini kaybetmelerinin ardından günlük ihtiyaçlara cevap verecek nitelikte bir işlevle yeniden değerlendirilmeleri dönemin ekonomik koşulları dikkate alındığında uygun bir çözüm olarak görülebilir. Ayrıca hamamlar ve hamam-gymnasiumlar gibi tüm Antik Dönem yapılarının yapı malzemesi (devşirme) olarak kullanımı da ekonomik açıdan elverişli bir tutum oluşturmaktadır. Bununla birlikte 5. yüzyıl ile birlikte işlevini kaybeden ve terkedilen hamamlar gibi büyük ölçekli yapı alanları yeni işlevler (özellikle kiliseler) için uygun alanlar olarak kullanılır.

Erken Bizans Dönemi sonrasında hamam yapılarının kullanıma iliş̧in bilginin kısıtlı olduğu yukarıda ifade edilmiştir. Bizans ve Orta Çağ kentlerindeki hamam yapılarının çoğunlukla, büyük ve kamuya açık olmasından ziyade daha küçük ve özel olduğu belirtilir. ${ }^{83}$ Konstantinopolis'teki büyük hamamlar bile 7. ve 8 . yüzyıllar boyunca ortadan kaybolmuştur. Hamamlar bu süreçte terk edilmiş ya da başka amaçlara hizmet etmek üzere dönüştürülmüştür. Böylelikle başkentte halk hamamı sayısı azalmış, hatta eyaletlerde daha da düşüş göstermiştir. Özel hamamlar buna göre daha fazla önem kazanmıştır. ${ }^{84}$ Dolayısıyla küçük kent hamamlarının (balneum), palaestra ve frigidariumu bulunmayan, genellikle basit bir mekân dizisi oluşturan iki ya da üç odalı mahalle hamamları olarak Erken Bizans Dönemi sonrası var olması gerektiği ifade edilir. Küçük ve özel işletmeler niteliğinde olduklarından onlardan söz edilmediği ve özel onurlara ya da adanmışlıklara sahip olmadıkları belirtilir. 12. ve 13. yüzyılda Konstantinopolis'te küçük hamamların varlığına ilişkin kanitlar bulunmaktadır. Doğunun Bizans toplumu, klasik dünyadan kendilerine kalan kurumlardan olan hamamları sınırlı olarak kullansalar da hamama girme kültürünü canlı tutarlar. ${ }^{85}$

Sonuç olarak, Bizans kentlerinde hamamların ve hamamgymnasiumların dönüşümünde kentsel arazi yetersizliğine yönelik bulunan çözümler dikkati çeker. Bununla beraber dinsel, ekonomik, siyasi ve askeri koşullarındaki dönemsel değişimin kent üzerinde belirleyici olduğu ve arazi kullanım kararlarında etkin rol oynadığ 1 anlaşılmaktadır. Hamam yapılarının kullanımının ise sınırlı olduğu ve özel yapılardan ibaret olabileceği belirtilebilir.

\footnotetext{
${ }^{82}$ Clive Foss, Ephesus after Antiquity: A Late Antique, Byzantine and Turkish City, Cambridge University Press, Cambridge, 1979, 54.

${ }^{83}$ Jacques Heers, Family Clans in the Middle Ages: A Study of Political and 


\section{KAYNAKÇA}

Alanyalı, Hüseyin Sabri; “Side 2011 Yılı Çalışmaları”, 34. Kazı Sonuçları Toplantısı, Cilt 3, Pegasus Görsel İletişim Hizmetleri, Çorum, 2013, s. 205-220.

Arslan, Nurettin \& Böhlendorf Arslan, Beate; Taşın Hayat Verdiği Kent Assos, (2. Bask1), Homer Kitabevi, İstanbul, 2014.

Arthur, Paul; Bizans ve Türk Dönemi’nde Hierapolis (Pamukkale), (Çev: N. Fırat), Ege Yayınları, İstanbul, 2006.

Atvur, Orhan \& Atvur, Ümit; Side, Aksoy Grafik Dizgi Matbaacılık, İstanbul, 1984.

Bayburtluoğlu, Cevdet; Yüksek Kayalığın Yanındaki Yer: Arykanda, Homer Kitabevi, İstanbul, 2003.

Bean, George E.; Eskiçağda Güney Kıyılar, (Çev: İnci Delemen \& Sedef Çokay), Arion Yayınları, İstanbul, 1999.

Caggia, Maria Piera; "Sekizgen Hamam”, Phrygia Hierapolisi Yeni Atlast: Kentin ve Nekropolislerin Arkeoloji Haritası, (Ed: Giuseppe Scardozzi), Ege Yayınları, İstanbul, 2015, s. 123.

Ceylan, Burcu; Batı Anadolu Bölgesinde Bulunan Antik Dönem Anıtsal Yapılarından Dönüştürülmüş Bazilika Planlı Kiliseler, Basılmamış Doktora Tezi, Hacettepe Üniversitesi Sosyal Bilimler Enstitüsü, 2000.

Clarke, Joseph Thacher; Bacon, Francis H. \& Koldewey, Robert; Expedition of the Archaeological Institute of America, Investigations at Assos, Drawings and Photographs of the Buildings and Objects Discovered during the Excavations of 1881, 1882, 1883, Bernard Quaritch Henry Sotheran \& Co., London, 1902-1921.

Çevik, Nevzat; "Rhodiapolis ve Kumluca Sınırlarındaki Diğer Antik Yerleşimler", Arkeolojisi, Tarihi, Doğası ve Tarımıyla Kumluca Rhodiapolis, (Ed: Nevzat Çelik), Kumluca Belediyesi Yayınları, Antalya, 2008, s. 9-72.

Çevik, Nevzat; Lykia Kitabı, Suna-İnan Kıraç Akdeniz Medeniyetleri Araştırma Enstitüsü, Antalya, 2015.

Çevik, Nevzat \& Bulut, Süleyman; “Andriake Doğu Hamamı: Bölgenin Hamam Mimarlığına Işık Tutan Yeni Bir Örnek”, Adalya, XVII, 2014, s. $221-262$.

D’Andria, Francesco; "Hierapolis 2002 Yı1ı Araştırma ve Kazı Çalışmaları", 25. Kazı Sonuçları Toplantısı, Cilt 2, T.C. Kültür ve Turizm Bakanlığ1, Ankara, 2004, s. 111-122.

D’Andria, Francesco; “Hamam-Kilise”, Phrygia Hierapolisi Yeni Atlası: Kentin ve Nekropolislerin Arkeoloji Haritası, (Ed: Giuseppe Scardozzi), Ege Yayınları, İstanbul, 2015, s. 96-97.

Dalgıç, Örgü \& Sokolicek, Alexander; “Aphrodisias”, The Archaeology of Byzantine Anatolia: From the End of Late Antiquity until the Coming of the Turks, (Ed: Philipp Niewöhner), Oxford University Press, New York, 2017, s. 269-279.

Dinç, Rafet; Tralleis, Arkeoloji ve Sanat Yayınları, İstanbul, 2003.

Dinç, Rafet \& Dede, Erkan; “Tralleis 1999 Kazısı Sonuç Raporu”, Arkeoloji ve Sanat Dergisi, 114, 2003, s. 11-24.

Equini Schneider, Eugenia; Doğu ile Batı Arasında Bir Liman Kenti Elaiussa Sebaste, Homer Kitabevi, İstanbul 2008.

Equini Schneider, Eugenia; "Elaiussa Sebaste: 2011-2012 Excavation and Conservation Works”, 35. Kazı Sonuçları Toplantısı, Cilt 3, Muğla Sıtkı Koçman Üniversitesi Yayınları, Muğla, 2014, s. 415-427.

Equini Schneider, Eugenia; “Elaiussa Sebaste: 2014 Excavation and Conservation Works”, 37. Kazı Sonuçları Toplantısı, Cilt 3, T.C. Kültür ve Turizm Bakanlığı Yayınları, Ankara, 2016, 479-492.

Erkoç, Serap; “Patara Liman Hamamı: Mimarisi ve Yapı Evrelerine Dair İlk Gözlemler”, Phaselis Disiplinlerarası Akdeniz Araştırmaları Dergisi, 4, 2018, s. 239-258.

Fellows, Charles; A Journal Written During an Excursion in Asia Minor, John Murray, London, 1838.

Foss, Clive; Ephesus after Antiquity: A Late Antique, Byzantine and Turkish City, Cambridge University Press, Cambridge, 1979.

Heers, Jacques; Family Clans in the Middle Ages: A Study of Political and Social Structures in Urban Areas, North-Holland Publishing, Amsterdam, 1977.

Işık, Fahri; "Patara 1992”, XV. Kazı Sonuçları Toplantısı, Cilt 2, Ankara Üniversitesi Basımevi, Ankara, 1995, s. 279-302.

Işık, Fahri; "Patara 1994”, XVII. Kazı Sonuçları Toplantısı, Cilt 2, T.C. Kültür Bakanlığı Milli Kütüphane, Ankara, 1996, s. 159-184.

Işı1k, Fahri; İşkan, Havva \& Çevik, Nevzat; MILIARIUM LYCIAE: Patara Yol Kılavuz Anıtı / Das Wegweisermonument von Patara, Akdeniz Üniversitesi Yayınları, Antalya, 2001.

Kazhdan, Alexander P.; The Oxford Dictionary of Byzantium, (Cilt 1), Oxford University Press, Oxford, 1991. 
Koder, Johannes \& Ladstätter, Sabine; “Ephesos, 2009”, 32. Kazı Sonuçları Toplantısı, Cilt 2, T.C. Kültür ve Turizm Bakanlığı Yayınları, Ankara, 2011, s. 278-296.

Ladstätter, Sabine; “Bizans Dönemi’nde Ephesos: Büyük Bir Antik Kentin Tarihinde Son Sayfa”, Bizans Dönemi’nde Ephesos, (Ed: Falko Daim \& Sabine Ladstätter), Ege Yayınları, İstanbul, 2011, s. 3-28.

Ladstätter, Sabine \& Pülz, Andrea; "Ephesus in the Late Roman and Early Byzantine Period: Changes in its Urban Character from the Third to the Seventh Century ad", The Transition to Late Antiquity, on the Danube and Beyond, (Ed: Andrew Poulter), Oxford University Press, Oxford, 2007, s. 391-433.

Lightfoot, Christopher; "Amorium”, The Archaeology of Byzantine Anatolia: From the End of Late Antiquity until the Coming of the Turks, (Ed: Philipp Niewöhner), Oxford University Press, New York, 2017, s. 333-341.

Lightfoot, Christopher \& Lightfoot, Mücahide; Amorium Anadolu'da Bir Bizans Kenti, Homer Kitabevi, İstanbul, 2007.

Mango, Cyril; "Daily Life in Byzantium”, Jahrbuch der Österreichischen Byzantinistik, 30, 1981, s. 337-353.

Mergen, Yalçın; Olympos Antik Kenti'nin Orta Çağ Dönemi Dokusu ve Likya Bölgesi Açısından Önemi, Basılmamış Doktora Tezi, Ege Üniversitesi Sosyal Bilimler Enstitüsü, 2011.

Moudon, Anne Vernez; “Urban Morphology as an Emerging Interdisciplinary Field”, Urban Morphology, 1, 1997, s. 3-10.

Naumann, Rudolf; “Ausgrabungen In Aizanoi 1983”, VI. Kazı Sonuçları Toplantısı, T.C. Kültür ve Turizm Bakanlığı Eski Eserler ve Müzeler Genel Müdürlüğü, İzmir, 1984, s. 379-390.

Niewöhner, Philipp; "Miletus", The Archaeology of Byzantine Anatolia: From the End of Late Antiquity until the Coming of the Turks, (Ed: Philipp Niewöhner), Oxford University Press, New York, 2017, s. 255-263.

Öztaşkın, Gökçen K. \& Öztaşkın, Muradiye; “Antalya-Olympos Mozaikli Yapı”, Uluslararası Genç Bilimciler Buluşması I: Anadolu Akdenizi Sempozyumu, Antalya, 2009, s. 329-346.

Poblome, Jeroen; Torun, Ebru; Talloen, Peter; Uytterhoeven, Inge; Hendrik, Uleners; Claeys, Johan; Van Beeumen, Roel; Ercan, Semih \& Ekinci, Hacı Ali; “Sagalassos’ta 2014 Yı1ı Kazı ve Restorasyon Çalışmaları”, 37. Kazı Sonuçları Toplantısı, Cilt 3, T.C. Kültür ve Turizm Bakanlığı Yayınları, Ankara, 2016, s. 83-106.

Procopius, The Buildings, (Çev: Henry Bronson Dewing), Loeb Classical Library, 1940.

Pülz, Andrea; “Bizans Dönemi’nde Ephesos’un Görünümü”, Bizans Dönemi’nde Ephesos, (Ed: Falko Daim \& Sabine Ladstätter), Ege Yayınları, İstanbul, 2011, s. 47-75.

Raeck, Wulf \& Rumscheid, Frank; "Die Arbeiten in Priene im Jahre 2009”, 32. Kazı Sonuçları Toplantısı, Cilt 3, T.C. Kültür ve Turizm Bakanlı̆̆ Yayınları, Ankara, 2011, s. 58-79.

Rumscheid, Frank; Priene: Küçük Asya'nın Pompeisi Rehberi, Ege Yayınları, İstanbul, 2000.

Saradi-Mendelovici, Helen; "The Demise of the Ancient City and the Emergence of the Mediaeval City in the Eastern Roman Empire", Echos du monde classique: Classical Views, 32 (3), 1988, s. 36-401.

Saradi, Helen G; The Byzantine City in the Sixth Century: Literary Images and Historical Reality, Society of Messenian Archaeological Studies, Athens, 2006.

Serdaroğlu, Ümit; Assos Bahramkale, Arkeoloji ve Sanat Yayınları, İstanbul, 1995.

Steskal, Martin; “Erken Bizans Döneminde Ephesos’ta Yıkanma ve Hamam Mimarisi”, Bizans Dönemi'nde Ephesos, (Ed: Falko Daim \& Sabine Ladstätter), Ege Yayınları, İstanbul, 2011, s. 77-94.

Stroth, Fabian; “Aezani”, The Archaeology of Byzantine Anatolia: From the End of Late Antiquity until the Coming of the Turks, (Ed: Philipp Niewöhner), Oxford University Press, New York, 2017, s. 327-332.

Yazıc1, Erdal; Aphrodisias ve Çevresi, Uranus Yayınevi, İstanbul, 2015.

Yegül, Fikret; The Bath-Gymnasium Complex at Sardis, Harvard University Press, Cambridge, 1986.

Yegül, Fikret; Antik Çă̆’da Hamamlar ve Yıkanma, (Çev: Emel Erten), Homer Kitabevi, İstanbul, 2006.

Yılmaz, Salim; Denizli, "Hierapolis (Pamukkale) Antik Kenti Roma Hamamı Sondaj Kazısı ve Temizlik Çalışmaları”, IV. Müze Kurtarma Kazıları Semineri, Ankara Üniversitesi Basımevi, Ankara, 1994, s. 199-218. 